\title{
Ultimate Acceptability, Cultural Bias, and an American Indian World: Reflections on Nelson Goodman
}

\author{
Thomas M. Norton-Smith \\ Kent State University \\ tnortons@kent.edu
}

\begin{abstract}
Nelson Goodman maintains that there is a plurality of internally consistent, equally privileged, well-made actual worlds constructed through the use of very special symbol systems - right or ultimately acceptable world versions. Using evidence from American Indian traditions, I will argue that Goodman's criteria for ultimately acceptability are culturally biased against any non-Western world version-especially a Native version. I will then offer a culturally sensitive interpretation of Goodman's criteria for ultimate acceptability that an American Indian world version satisfies, and so is numbered among the internally consistent, equally privileged, well-made actual worlds.
\end{abstract}

Keywords: American Indians; constructivism; cultural bias; Goodman; ultimate acceptability; world versions.

Resumen. Aceptabilidad última, prejuicio cultural y un mundo nativo-americano: Reflexiones sobre Goodman

Nelson Goodman sostiene que hay una pluralidad de mundos internamente consistentes, igualmente privilegiados, bien construidos y reales que se erigen mediante el uso de sistemas simbólicos muy especiales, a saber, versiones de mundo correctas o en última instancia aceptables. Utilizando como evidencia algunas tradiciones de los indios americanos, argumentaré que los criterios de Goodman para la aceptabilidad última están culturalmente sesgados en detrimento de cualquier versión del mundo no occidental, en particular, una versión nativa. Ofreceré entonces una interpretación culturalmente sensible de los criterios de Goodman para la aceptabilidad última satisfechos por una versión del mundo de los indios americanos, de modo que se cuente entre los mundos internamente consistentes, igualmente privilegiados, bien construidos y reales.

Palabras clave: Nativo Americanos; constructivismo; prejuicio cultural; Goodman; aceptabilidad última; versiones del mundo. 


\author{
Summary \\ 1. Introduction \\ 4. An American Indian Well- \\ 2. Ultimate Acceptability \\ made Actual World \\ and Well-made Worlds \\ References
}

3. True Versions and Cultural Bias

\title{
1. Introduction
}

kiwaakomelepwa! nitesi8o Thomas Norton-Smith. saawanwa nilla no'ki ni m'soma peleawa. Greetings to you all! I am Thomas Norton-Smith. I am Turkey clan Shawnee Indian. These reflections recall and renew my recent book (Norton-Smith 2010), wherein I presented one possible interpretation of American Indian "philosophy» based upon a culturally sophisticated interpretation of Nelson Goodman's constructivism.

Professor Goodman maintains that there is a plurality of internally consistent, equally privileged, well-made actual worlds constructed through the use of very special symbol systems - right or ultimately acceptable world versions. I will gently suggest that Goodman's criteria for ultimately acceptability are culturally biased against any non-Western world version-especially an American Indian version. I will then offer a culturally sensitive interpretation of Goodman's criteria for ultimate acceptability that an American Indian world version satisfies, and so should be numbered among the internally consistent, equally privileged, well-made actual worlds. My remarks are not to be construed as a criticism of Goodman; indeed, it strikes me that far too many philosophers these days are gleefully and rudely critical of others.

\section{Ultimate Acceptability and Well-made Worlds}

Professor Goodman's first fundamental insight is that «facts are fabricated," that the notion of a mind-independent world of facts is mistaken ( WW, 91-107). As an illustration, I have often used my backyard bird feeder, visited on one particular occasion by a trio of cardinals. In our everyday way of thinking about the world, the "facts» are that there were three cardinals around the feeder; the cardinal atop the feeder was red; there was one natural kind — the cardinal - exemplified by the birds around the feeder; there were no persons around the feeder; it is the same feeder as the one I repaired last year; and, the feeder was not moving. These "facts» make true the corresponding statements about the red cardinals around my stationary feeder, and I know these things because my true beliefs are justified (Norton-Smith 2010, 17-19). Only quibblers, I think, would object.

So, the statement, «The feeder was not moving» is true. It is striking, then, that according to NASA astrophysicists, I, my feeder, and its avian guests were 
moving at 67,000 miles/hour, the speed at which the Earth races around the sun (NASA). One wonders, then, how two contradictory statements, «The bird feeder was not moving» and «The bird feeder was moving,» can be true in virtue of two competing facts. Goodman's explanation is on the mark: Each of the statements is true relative to a different frame of reference-a version or description of the world. Under a geocentric frame of reference the feeder is not moving, and under a heliocentric frame of reference the feeder is moving $(W W, 2)$. A «frame of reference»- a world version - is grounded in the categorization and ordering of sense experiences employing linguistic symbols; that is, a version of the world is grounded in the fabrication of facts through the devices of a language. There are no "bare facts» of the matter! !

The remarkable thing is that there are many possible versions of my backyard world that are consistent with my experiences, because the content of our sense experiences underdetermines how the world really is. Some of those alternative versions sound quite odd. For example, in a frame of reference wherein «red» is regarded as an intransitive verb like «moves,» then the statement «The cardinal atop the feeder redded» is true, while «The cardinal atop the feeder was red» is not. In a frame employing the predicate «bleen»-where a thing is bleen if it is either blue or green-it is true that «The cardinal atop the feeder was not bleen.» In Goodman's preferred nominalist frame, it is true that "There were three individual cardinals at the feeder," but no fourth entity, the abstract natural kind they exemplified. «There was cardinal at the feeder» is true in a frame wherein "cardinal» is treated as a mass noun like "water.» Finally, in a Quinean (Quine 1981) sort of frame of reference wherein material objects come in temporal slices, it is false that "It was the same feeder I repaired last year.» These are some odd facts indeed, for most contradict our habit of thinking and talking about the world, our preferred linguistically categorized and ordered frame of reference-but not one of them is inconsistent with the content of our sense experiences!

I argued that some of these odd sounding «facts» are quite at home in American Indian world versions. Many American Indian languages like Shawnee, lacking the verb "to be,» treat English adjectives like «red» as intransitive verbs (Wagar, pers. comm. See also Hester 2004, 264-5 and Cajete 2000, 26-7). So, a Shawnee speaker commenting on my backyard scene might say "meci skwaawa,» expressing about the cardinals the fact that «They redded.» As well, the Shawnee stem «skipaky-» applies to a thing if it is either blue or green - or better said, if the thing bleens (Voegelin 1939, 314). And while "There were no persons around the feeder» is true in the Western version,

1. The speciousness of the bare fact as an epistemological foundation is a common theme in constructivist thought, for the pure content of sense experiences alone underdetermines how the world really is. Indeed, as Goodman argues, one cannot even describe what the pure given might be apart from the order or structure imposed by a description, for a description must be employed in the account $(W W, 6)$. Thus, the question whether my feeder was really moving or not is empty, for without a conceptualizing intellect utilizing a system of description, there was no fact. 
in the Native frame of reference the fact is that there were three persons around the feeder (Norton-Smith 2010, 21-22).

Since the content of our sense experiences underdetermines the way the world really is, there are many possible interpretations - world versions - of the events taking place in my backyard. In an English version, the cardinals were red; in a Shawnee version, they redded. But to say that «there are many possible interpretations» somewhat misrepresents Goodman's view, for he famously argues for ontological pluralism, that there are many actual ontologically diverse, yet equally privileged constructed worlds ${ }^{2}$. Ontological pluralism rests upon the premise that all of the characteristics of the world - the things we understand to be objects and kinds - are relative to a particular model, theory, or version. This is nicely illustrated by the multiple isomorphic settheoretic reductions of the natural numbers. While the statement «The number 2 is $\{\{\phi\}\} »$ is true in Zermelo's model, it is false in von Neumann's, in which it is true that «The number 2 is $\{\phi,\{\phi\}\}$.» The question, «What is the number 2 really?» makes no sense.

Importantly, Goodman does not believe that all descriptions of the world are «true» or right. Indeed, the Lowenheim-Skolem theorem guarantees that there are non-standard models of first-order number theory, but no non-standard model can be "true» or right. That is,

[The] willingness to accept countless alternative true or right world-versions does not mean that everything goes, that tall stories are as good as short ones, that truths are no longer distinguished from falsehoods, but only that truth must be otherwise conceived than as correspondence with a ready-made world. Though we make worlds by making versions, we no more make a world by putting symbols together than a carpenter makes a chair by putting pieces of wood together at random. The multiple worlds I countenance are just the actual worlds made by and answering to true or right versions. Worlds possible or impossible supposedly answering to false versions have no place in my philosophy. (WW, 94)

In the absence of truth construed as correspondence to theory independent facts, how does Goodman distinguish between «true» versions - versions that make actual worlds - and "false» versions that do not? True versions exhibit acceptability, a kind of rightness that is closely related but different from truth, and ultimate acceptability «serves as a sufficient condition for truth» $(M M, 38)$. Ultimately acceptable versions satisfy a number of conditions or «standards of rightness»: deductive validity and inductive rightness, utility and simplicity, and non-emptiness. Now, these standards are not weighted equally when determining whether a version is acceptable. However, in Goodman's view — and in mine as well - the violation of some of them renders a version unacceptable.

2. "What we often mistake for the actual world is one particular description of it. And what we mistake for possible worlds are just equally true descriptions in other terms. We have come to think of the actual as one among many possible worlds. We need to repaint that picture. All possible worlds lie within the actual one» $(F F F, 57)$. 
First, Goodman maintains that «[a]mong the most explicit and clearcut standards of rightness we have anywhere are those for validity of a deductive argument» (WW, 125). That is, a version which violated the logical laws governing validity - a version in which one could deduce a statement and its negation - would be unacceptable. Indeed, every statement is deducible - must be true - in such a version!

Strong induction is the second standard of rightness, where inductive strength requires both the usual formal relations between premises and conclusions, but also right categorization. Think back to our earlier predicate «bleen» - or better still to our earlier Shawnee intransitive verb «skipaky-.» While the English predicate "green" is projectible, and past observations confirm the general hypothesis that all emeralds are green, «skipaky-» is not projectible in an English world version, so concluding that «skipaky- applies to all emeralds»—-that is, «all emeralds either green or blue»—based upon past observations would be inductively weak, hence unacceptable. «skipaky-» wrongly categorizes experiences of color in the English world version. A long history of past inductive successes weights "green" more heavily than "skipaky-.» Clear evidence, according to J. W. Powell, of American Indian «savagery»:

[I]n savagery ... blue and green are not differentiated, for the Indian sees but one color, and has but one name; the green grass and the blue heavens are of the same hue to the Indian eye. (Powell 1877, 4)

The utility of a theory or version is a third standard of rightness; indeed, nothing is more useful in Newtonian physics than the fictional frictionless plane or the myth of uniform three-dimensional space. But, our bridges tend not to fall down - especially in states with Democratic governors - thanks to the useful fictions of the physics of breadbox sized objects.

Simplicity, according to Goodman, is a fourth and pretty important standard of rightness for versions:

My insistence that simplicity is of the essence of science has sometimes been misinterpreted as the claim that simplicity is the only or the always-overriding factor in the choice of basis. Obviously, considerations such as brevity, clarity, convenience, familiarity, and utility for a special purpose usually enter also ... but these other factors, unlike simplicity and truth, are minor aids rather than major aims. A scientific system may be cumbersome, difficult, strange; but with no simplicity we have no system and no science at all. $(P P, 277)$

So, given two versions, the one that posits fewer primitive objects, relations, and complex processes is the more acceptable. Indeed, it was simplicity that gave the Copernican model of planetary motion a toehold in competition with its deeply entrenched Ptolemaic rival.

Finally, Goodman's constructivism suggests that there is one final and critically important standard for the rightness of a version: If a version speaks of objects or kinds that are empty - that organize or categorize no sense experiences whatsoever - then the version is unacceptable. Whether sense experiences are 
categorized such that "The cardinals were red» is true or «The cardinals redded» is true - statements whose perceptual content is identical — there must be sense experiences to organize. I made the point using the following analogy:

[T] he unstructured content of sense experience can no more be a world version than a rowdy gathering without rules of order can be a meeting. On the other hand, could we have a meeting with the rules of order in place, but without the gathering? Clearly not — the meeting hall would be empty. Likewise, a statement, theory, model or version is empty when there is no perceptual content to be identified, categorized, and organized by language. (Norton-Smith 2010,35)

No wonder Goodman rejects powers or dispositions, counterfactual assertions and other possibilia, as well as «neutrinos, angels, devils, and classes» - all notoriously imperceptible, and so empty notions (FFF, 33).

This all too brief treatment of Goodman's standards of rightness is more extensively considered in Norton-Smith (2010). The important point here is that models, theories or versions that conflict with our deeply entrenched beliefs, accepted precepts, habits of mind and the evidence of perception will be unacceptable - hence «false.» On the other hand, world versions that satisfy at least Goodman's more important standards of acceptability aspire to ultimate acceptability, and such versions construct well-made, actual worlds.

\section{True Versions and Cultural Bias}

We have noted Professor Goodman's «willingness to accept countless alternative true or right world-versions» as well as his unwillingness to accept just any world version. "True» versions are ones that are extensionally isomorphic to an ultimately acceptable version, where the criteria or standards for ultimate acceptability include deductive validity and inductive rightness, utility, simplicity and non-emptiness, i.e., having a basis in sense experience ${ }^{3}$. However, these standards are largely culturally determined, and so Goodman's constructivist account is biased against American Indian versions and worlds ${ }^{4}$.

3. Extensionally isomorphic versions may be ontologically diverse, but their overall global structures are preserved. See Norton-Smith (2010, 26-32).

4. Goodman (1964) anticipates a similar objection — the charge of «bigotry» — in an earlier defense of nominalism. "Nominalism is bigoted,» so goes the objection, in that its adoption is governed by a «supposed insight into its intrinsic merits and defects» and not by an appeal to "getting better results.» He answers:

The nominalist cannot demonstrate the need for the restrictions he imposes upon himself. He adopts the principle of nominalism in much the same spirit that he and others adopt the principle of extensionality or that logical philosophers in general adopt the law of contradiction. None of these is amenable to proof; all are stipulated as prerequisites of soundness in a philosophic system. They are usually adopted because a philosopher's conscience gives him no choice in the matter. This does not mean that he need deny that he might some time change his mind. If ... pushe[d] ... hard enough, I will even concede that I might some day give up the law of contradiction 
"Among the most explicit and clear cut standards of rightness we have anywhere," according to Goodman, is valid deduction - as defined in Western classical two-valued semantics - which assumes the laws of contradiction and excluded middle ( $W W, 125)$. Thus, this «most explicit and clear cut standard of rightness» - one that Goodman's conscience "gives him no choice in the matter» $(P P, 170)$ - begs the question against any other «nonstandard» logics as standards of rightness. I find this odd, since a constructivist like Goodman ought to recognize that, since, patterns are where you find them, and a logic is just another way to organize and categorize experiences, there are many possible logics that could be employed, e.g., intuitionist logics, which embrace the law of contradiction, but deny the law of the excluded middle. To our point, Goodman's standard of valid deduction is biased against American Indian versions and worlds.

Anne Waters (2004a, 97-99) explains that Native thought is framed by a logic decidedly different from Western logics - a nondiscrete complementary dualist logic. Such logics welcome male/female, good/evil, and animate/inanimate dualisms, but, being nonbinary, these dualisms are not regarded as opposites. Moreover, in such logics where dualisms are complementary, it may be the case that something is both $p$ and not- $p$ at the same time in the same sense, without one excluding the other. For example, a person may have elements of male and female at the same time - without the one excluding the other. Good and evil can — and often do — simultaneously reside in the same event. Goodman would most certainly deem unacceptable a logic that denies the law of the excluded middle - and especially the law of contradiction - unless "pushed hard enough" $(P P, 170)$. But then, my remarks are only a "gentle suggestion.»

Goodman's standard of inductive rightness is no less biased against American Indian processes of induction, for the formal relations between premises and conclusions required for the strong inductive inferences - strong by Western lights, that is - are, like their deductive counterparts, culturally biased against nonstandard processes of projection. For, every informal logic text teaches that strong inductive generalizations require well-established regularities - and the better the regularity, the stronger the projection into the future. Who would seriously question that all men are mortal, that all emeralds are green, or that fire burns uncovered skin? However, American Indian processes of projection are more cautious, for two reasons. The first - and the most fundamental way that Native people organize and categorize experiences — is the conviction that «everything is related.» Second, Indians believe that the world is not inert and mechanistic, fixed and finished, but is, instead, animate, creative, and constantly unfolding (Norton-Smith 2010, 45-49).

in the interests of getting better results - although if I should give up the law I am puzzled about what the difference would then be between getting results and not getting results.» $(P P, 169-170)$

My similar objection is that Goodman's standards for ultimate acceptability-while «intrinsically meritorious» by his lights — are culturally biased against Native world versions. 
First, because all entities and events in the Native constructed world are related, the process of categorization necessary for right inductions constantly evolves. They actively search for newly emergent, previously overlooked, unexpected, and strikingly unusual connections between experiences, employing what I call relatedness as a world ordering principle. According to Lakota Vine Deloria, Jr. the Pawnee had discovered a plant-plant relationship, using the milkweed as an indicator plant to tell how their corn crop was progressing some two weeks away. I would say that in the Pawnee world version there was a useful relationship constructed between milkweed and corn maturing experiences (Deloria 1999b, 35).

Second, the predominant Western ontological assumption about the physical world is that it is material and inanimate, mechanical and rational, amenable to quantitative description and governed by fixed physical laws. It is orderly, fixed, and finished. No wonder the principle of induction - that very well-established regularities will extend into unobserved regions of space and time - is a premise in right induction. However, the Native version constructs a world that is creative and animate, dynamic and interconnected, unfixed and unfinished. In such a world it would be somewhat reckless to extend even the best verified regularity — to project the most well-entrenched predicate —into the future with unflinching confidence. How could the mortality of every past human being preclude the mortality of every future one in a dynamic and unfolding world? (Deloria 1999a, 50).

Utility, as a standard for the ultimate acceptability of a theory or version is no less culturally informed, for within the context of any frame of reference one must ask, "Useful for whom and for what purpose?» A very useful version for the Western tradition, which constructs an inert and material, law-like and mechanical, but a sometimes threatening natural world, is the one that best enables us to explain and predict, and then conquer, manipulate and exploit $\mathrm{it}^{5}$. However, Indians are not as concerned with conquering and manipulating the natural world as finding «the proper road along which, for the duration of a person's life, individuals [are] supposed to walk» (Deloria 1999a, 46). The useful version, then, in a world Deloria terms a «moral universe,» is a normative one. It does not look at the world as an inert natural resource and ask «How can I predict, manage, or defeat this?» Instead, it sees a living community in which human beings participate and asks "How should I behave?» So, like the deductive and inductive rightness of world versions, utility as a criterion of ultimate acceptability is culturally determined.

Returning to our consideration of Goodman's standards for the acceptability of a world version, I offer a brief and dismissive critique of simplicity: There is no non-question begging argument that the best version of the world will

5. Indeed, when considering whether the pragmatists' proposal that truth should be interpreted in terms of utility, Goodman muses that "[ $\mathrm{t}] \mathrm{he}$ thesis that true statements are those that enable us to predict or manage or defeat nature has no little appeal» (WW, 122-123; emphasis added). 
be the simplest one. For, a realist ought to believe that science should discover that the natural world is simple, not assume that it is, and a constructivist's choice of the simplest theory from among rivals reflects more an aesthetic preference than a robust standard of acceptability — «the more elegant theory is the more acceptable.» But what could be more culturally informed than one's aesthetic preferences? (Norton-Smith 2010, 50-51).

Unlike deductive validity and inductive rightness, utility and simplicity - all of which have cultural components, interpretations, or understandings whether or not a world version is empty is not culturally determined. Indeed, Goodman is exactly right that one cannot construct a world without sense experiences to identify and organize. Western philosophers often use words without creating a world - consider Platonic «forms,» Cartesian "causality,» and Lockean «natural rights.» But such empty versions do not construct wellmade worlds. And while space now prohibits a full development of the claim, I argue at length that an American Indian world version is not empty - even in its use of the term "manitooki,» translated as «spirits»! (Norton-Smith 2010, 86-88).

\section{An American Indian Well-made Actual World}

I have argued that Goodman's standards for the ultimate acceptability of a world version - deductive validity and inductive rightness, utility and simplicity - are culturally informed or determined. By these standards, only Western world versions are ultimately acceptable; only Western world versions construct well-made actual worlds. Non-Western versions embracing different notions of deduction or induction, a different sense of utility, or that posit complex relationships between vast numbers or bizarre kinds of primitive entities are unacceptable, hence give rise to ill-made or impossible worlds. I believe, by the way, that Professor Goodman would not disagree with this assessment.

However, this kind of «cultural superiority» — the «natural» conviction that one's own familiar tradition is the only correct one - is difficult to justify. I propose, then, that we interpret these standards for ultimate acceptability in a culturally sophisticated way that recognizes their inherent bias. In judging whether or not a world version satisfies standards for rightness we should consider for whom the world version is ultimately acceptable, introducing the notion of a cultural frame of reference. Goodman provides standards of ultimate acceptability for a 20th century Western analytic philosopher - but they are not the standards acceptable for a traditional Shawnee Indian. So, when judging deductive and inductive rightness, we determine whether inferences are consistent with the principles of deduction and inductions adopted within that particular cultural frame of reference. When judging utility, we ask whether a version achieves a purpose or goal informed by the cultural frame. Before requiring simplicity, we consider the aesthetic standards in the cultural frame. Of course, emptiness is not culturally determined, so a culturally sophis- 
ticated reinterpretation of Goodman's standards will not sanction the construction of an actual world with an empty version.

In the view I advance, a version satisfying these culturally informed standards will be ultimately acceptable within a cultural frame, and so will construct a well-made actual world. Anyway, all world versions - frames of reference - are cultural frames of reference:

[I]ndeed, all that we have done here is to make explicit the implicit cultural nature of a version. Facts are fabricated, but the fabrication takes place within a linguistically informed tradition; I see a red cardinal atop my feeder, but not a cardinal redding atop the feeder. And what could be more culturally infused and determined than the linguistic frame of reference in which statements, theories and models are embedded? (Norton-Smith 2010, 53)

I argued in Norton-Smith (2010) that an American Indian world version satisfies this culturally sophisticated reinterpretation of Goodman's standards, and so is ultimately acceptable within a Native cultural frame of reference. Thus, an American Indian world will be numbered among the internally consistent, equally privileged, well-made actual worlds, and so it is worthy of philosophical treatment — and respect - from the Western perspective. In a Native world, sense experiences are organized and categorized - objects and kinds are constructed - employing at least four world constructing principles that seem to recur across American Indian traditions - relatedness, circularity, an expansive conception of persons, and the semantic potency of performance. While there is neither ample time nor space to explore these themes now, I cannot end without expressing admiration for and gratitude to Professor Goodman.

\section{References}

Cajete, G. (2000). Native Science. Santa Fe, NM: Clear Light Publishers.

Deloria, B., Foenner, K., and Scinta, S. (eds.) (1999). Spirit and Reason. Golden, CO: Fulcrum Publishing.

Deloria, Jr., Vine (1999a). «If You Think About It, You Will See That It Is True.» In: Deloria, Foenner, and Scinta (1999). Spirit and Reason. Golden, CO: Fulcrum Publishing, 40-62.

- (1999b). «Relativity, Relatedness, and Reality.» In: Deloria, Foenner, and Scinta, (1999). Spirit and Reason. Golden, CO: Fulcrum Publishing, 32-39.

Goodman, N. (1955). Fact, Fiction, and Forecast. Cambridge: Harvard University Press.

- (1972). Problems and Projects. Indianapolis: Bobbs-Merrill.

- (1978). Ways of Worldmaking. Indianapolis: Hackett.

- (1984). Of Minds and Other Matters. Cambridge: Harvard University Press.

Hester, T. L. (2004). «On Philosophical Discourse: Some Intercultural Musings.» In: WATERS, A.. American Indian Thought. Oxford: Blackwell, 263-267. 
NASA (2005). «Speed of the Earth's Rotation.» Accessed 12 May 2007. <http:// imagine.gsfc.nasa.gov/docs/ask_astro/answers/970401c.html>.

Norton-Smith, T. (2010). The Dance of Person and Place. Albany, NY: State University of New York Press.

Powell, J. (1877). Outlines of the Philosophy of the North American Indians. New York: Douglas Taylor, Book, Job and Law Printer.

Quine, W.V.O. (1981). World \& Object. Cambridge: MIT Press.

Voegelin, C. F. (1939). "Shawnee Stems and the Jacob P. Dunn Miami Dictionary.» Indiana Historical Society Prehistory Research Series 1 (8), 289-341.

Waters, A. (ed.) (2004). American Indian Thought. Oxford: Blackwell.

- (2004a). «Language Matters: Nondiscrete Nonbinary Dualism.» In: Waters, A.. American Indian Thought. Oxford: Blackwell, 97-115.

Thomas M. Norton-Smith, an enrolled member of the Piqua Sept Shawnee Tribe, is Professor of Philosophy at Kent State University. He earned the PhD from the University of Illinois at Urbana-Champaign. Norton-Smith's professional interests include the philosophy of mathematics and American Indian philosophy. He most recently authored The Dance of Person and Place: One Interpretation of American Indian Philosophy, State University of New York Press, 2010.

Thomas M. Norton Smith, miembro inscrito a la tribu Piqua Sept Shawnee, es profesor de filosofía en Kent State University. Obtuvo su doctorado de la University of Illinois en UrbanaChampain. Sus intereses profesionales incluyen la filosofía de las matemáticas y filosofía nativoamericana. Su obra más reciente es The Dance of Person and Place: One Interpretation of American Indian Philosophy, State University of New York Press, 2010. 